\title{
Gamification Framework for Programming Course in Higher Education
}

\begin{tabular}{c}
\hline Winanti ${ }^{1.2}$ \\
${ }^{1}$ Scholar of Doctor of Computer \\
Science, BINUS Graduate Program, \\
Bina NusantaraUniversity, Jakarta, \\
Indonesia 11480 \\
2Information System Departement, \\
STMIKInsan Pembangunan, \\
Tangerang, Indonesia15810 \\
${ }^{1}$ winanti@binus.ac.id; \\
${ }^{2}$ winanti12@ipem.ac.id \\
Yaya Heryadi \\
${ }^{3}$ Computer Science Departement, \\
BINUS Graduate Program - Doctor of \\
Computer Science, \\
Bina Nusantara University, \\
Jakarta, Indonesia 11480 \\
yayaheryadi@gmail.com
\end{tabular}

\author{
Bahtiar Saleh Abbas \\ Computer Science Departement, \\ BINUSGraduate Program - Doctor of \\ Computer Science, \\ Bina Nusantara University, \\ Jakarta, Indonesia 11480 \\ bahtiara@binus.edu \\ Agung Trisetyarso \\ Computer Science Departement, \\ BINUSGraduate Program - Doctor of \\ Computer Science, \\ Bina Nusantara University, \\ Jakarta, Indonesia 11480 \\ atrisetyarso@binus.edu
}

\author{
Wayan Suparta \\ Civil Engineering Department \\ University of Technology Yogyakarta, \\ Yogyakarta, Indonesia \\ drwaynesparta@gmail.com
}

\begin{abstract}
This paper presents a gamification framework for higher education, especially for programming language courses to increase user motivation, pleasure and satisfaction so that learning objectives can be achieved. Although student and lecturer motivation, pleasure, and satisfaction tend to increase compared to conventional techniques, gamification is not a panacea. The success of its application depends on the skill of the lecturer in choosing a game mechanic to give a sense of playing to the learning process in a more interesting way. The technique is done by dividing the class into two parts where one class uses the conventional method and one class uses the gamification method and the results will be evaluated through the assessment results before using the gamification method and after using the gamification method. The framework in this paper adds to the existing framework activities, namely adding in the field of baseline analysis, learning materials and tools used in gamification, where previous papers from three activities have not been discussed in detail. The results obtained turned out that using the gamification technique of student learning outcomes on average 15 to 25 better than using conventional techniques.
\end{abstract}

Keywords-gamification, education, introductory
programming

\section{INTRODUCTION}

Gamification was defined as "the process of gamethinking and game mechanics to engage users and solve problems." [1]. Gamification as "the use of game design elements in non-game contexts." [2]. Gamification is different from game-based learning (GBL). Whilst the former only used a number of game elements such as badges, point system, difficulty levels, quests and avatars; GBL ask students playing particular games into which the predefined learning outcomes was embedded.
In the past ten years, gamification techniques have attracted educators and teachers to adopt this technique to achieve the following main objectives: a). increase students engagement [3], [4] and b). personalization of student learning process [5], [6]. The strength of gamification in education is its remarkable power to encourage and motivate students engagement for their enjoyment. It is expected this power will help students to achieve learning outcomes. [7]

Despite many studies reported much evidence on successful gamification in education, study findings [7], [8] concluded gamification in education is still a challenging problem. The study has validated several key success factors for successful adoption of gamification in education namely: the course material and learning objectives, the holistic structure of the learning experience, specific elements and mechanisms to guide the student achieving learning experience.

This study aims to develop a gamification framework for teaching programming course in colleges to increase student's learning engagement and participation. The framework was planned to be tested to students taking programming course in their first year at Higher Education.

The rest of this paper is organized as follows. Part 2 will describe a number of related works. Part 3 will explain research method followed by research findings and discussion in part 4. Finally, Part 5 will conclude this paper.

\section{RELATED WORKS}

In last decade, a plethora of reports on gamification research resulted in several proposed frameworks available in literature. For example, proposed a social gamification framework to improve learning of K-6 students. [9]. 


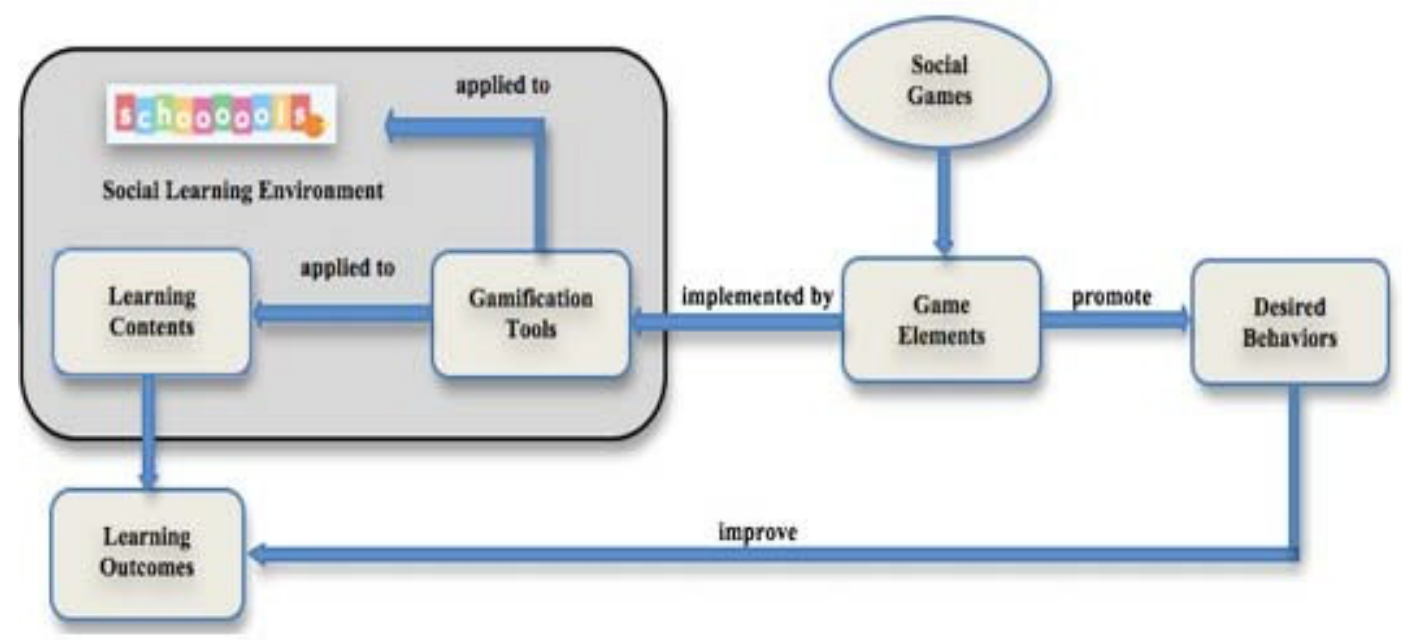

Fig.1. Gamification framework for K-6 education (Source: Simões, Redondo \& Vilas, 2013) [9]

This gamification framework was later revised (see Fig. 2 ). Unlike the previous one, the proposed framework clearly defined the key factors that affect the change in terms of student's behaviors, immersion, emotions and mechanic (psychomotoric). [10].

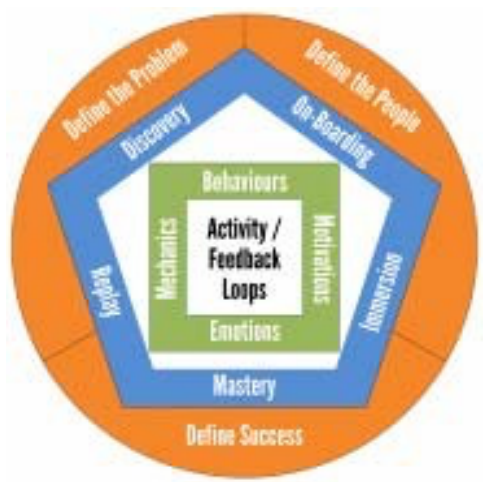

Fig.2. Gamification framework (Source: Tondello, Wehbe, Diamond, Busch, Marczewski \& Nacke, 2016)

From implementation side, [7] showed some evidences that some design techniques contributed to achievement of gamification objectives in education context such as : a). visual status, b). social engagement, c). freedom of choice, d). freedom to fail, and f). rapid feedback. The authors also noted that, unlike entertainment game, gamification less exploit the following game design elements such as: goals, personalization, unlocking content, storyline, onboarding and time restriction.

\section{GAMIFICATION FRAMEWORK DEVELOPMENT METHOD}

The proposed gamification framework for education context comprises the following activities (see Fig. 3). The main activities are [11]:

1) Participant identification to identify all actors involve in the teaching and learning process are arranged systematically according to the competency standards set to achieve learning objectives. While the gamification tool can help lecturers and students in the learning process and be able to maximize the teaching-learning process.

2) Objective identification aims to identify the main objective of gamification in education and to select main objective as main priorities due to predicted impact to learning outcome and student learning satisfaction.

3) Implementation aims to use various game mechanics necessary to improve student's participation and engagement in delivering learning materials.

4) Learning evaluation to measure effectiveness of learning in terms of learning achievement, playability, and satisfaction.

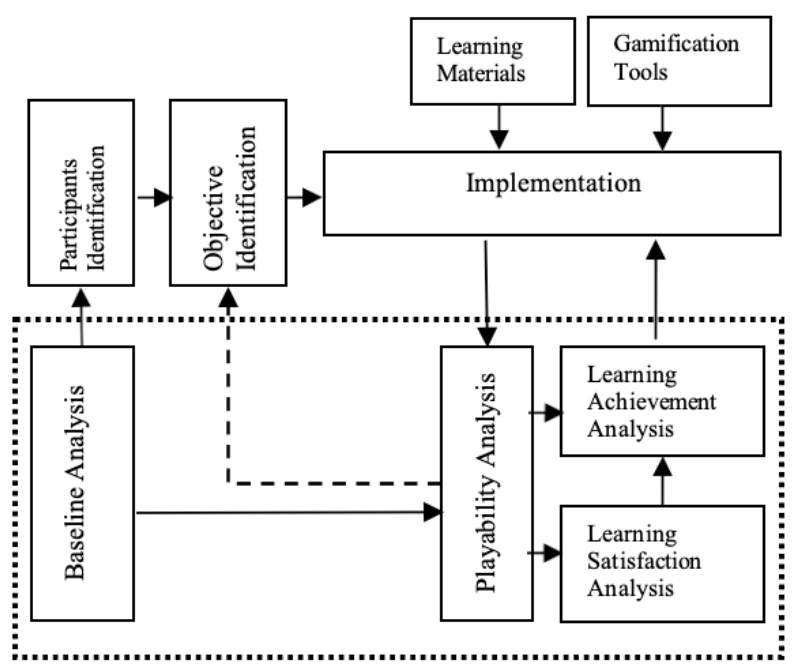

Fig. 3. Gamification Framework for Education

The proposed framework has additional components, namely: baseline analysis, learning material, and gamification tools. Baseline analysis as basic information is arranged before a program starts and as a comparison tool in estimating the impact of the program before and after the program is implemented. Learning materials to assist lecturers in the activities of motivation, feelings of enjoyment and engagement towards the learning process. 


\section{StUdy RESUlts AND DiscUSSION}

Existing Teaching and Learning Problem Analysis From our observations in the last 2 semesters, there are several main problems in providing learning in higher education, namely :

a) Students find it difficult to understand the basic concept of teaching materials delivered by lecturers.

b) Students tend to be less creative in trying new approaches to solve problems given (just follow the example of lecturers given in the classroom without being creative).

c) Low participation in class discussion.

d) Low collaboration: students tend to workindividually.

e) Low motivation : lecturers hesitate to change learning modules.

f) Low engagement : students tend to easily get bored with the lecturer teaching styles.

g) Low rate of student's learning achievement.

\section{- Participant Identification}

In the teaching-learning process, the main actors are students, lecturers, and teaching assistants. Although this framework will be tested fully to a class in one semester duration, some partial testing to the framework is being progressed.

In the initial test, several students enrolled in the class were divided into two groups. Each group has 20 students with the same proportion of females and males. It is assumed that the student profiles in each group is homogeneous. Study material in each group will be delivered as follows :

Group 1 uses conventional technique, and group 2 uses gamification techniques. Before the experiment begins, to obtain baseline data, each participant is required to fill out a self-administered questionnaires and brief interview conducted by lecturers.

\section{- Objective Identification:}

In general, the gamification main objectives in Introductory programming are to improve students learning achievement in the following topics:

a) Basic concept of program, program structure and program execution

b) Variables and data types

c) Control structures

d) Basic concept of algorithm and implementalgorithm in program

e) Functions

f) Strings

g) File Input and Output

h) The gamification technique, in particular, focuses onimproving student's mastery on basic syntax of the given programming language and reducing programming error in a fun way.

- Implementation
Implementation steps can be divided into: preparation, main process, closing steps. In the first steps, member of lecturers who participate in this activity was informed on objectives, research procedures, expected outcomes, a set of game mechanics, and learning achievement measurement metric. It is assumed that the learning types to be supported by the gamification for education are individual and collaborative (group) learning. Each learning objective is mapped to each of the selected game mechanic. Several gamification elements can be adopted such as: game leaderboard to acknowledge the top learning achiever, social engagement or collaboration media, freedom of choices (allowing student to choose learning material or exercise), freedom to fail (allowing student to reread learning material or repeat solving the exercise) and rapid feedback from lecturers.

Table 1. Implementation of gamification

\begin{tabular}{|c|c|}
\hline $\begin{array}{c}\text { Game } \\
\text { mechanic }\end{array}$ & Implementation \\
\hline $\begin{array}{l}\text { Completing } \\
\text { quest }\end{array}$ & $\begin{array}{l}\text { Lecturers use the concept of quest, } \\
\text { students can submit their work that can } \\
\text { strengthen the norms or rules in learning }\end{array}$ \\
\hline Point & $\begin{array}{l}\text { Students who are able to answer are } \\
\text { given certain points / values to be more } \\
\text { challenged and motivated }\end{array}$ \\
\hline Badges & $\begin{array}{l}\text { Students answer correctly will be given a } \\
\text { badges so students are challenged to } \\
\text { answer the next question }\end{array}$ \\
\hline Level & $\begin{array}{l}\text { Every student activity in programming } \\
\text { language learning is given a value that } \\
\text { can affect the level and the lecturer } \\
\text { separates the material into different } \\
\text { levels and tiered to see how far the level } \\
\text { of student mastery }\end{array}$ \\
\hline Challenges & $\begin{array}{l}\text { Students who succeed through one stage } \\
\text { will be given a challenge so that their } \\
\text { confidence increases. If students } \\
\text { experience difficulties, the lecturer does } \\
\text { not reduce the level of difficulty but } \\
\text { helps students solve the challenge. }\end{array}$ \\
\hline Leaderboard & $\begin{array}{l}\text { Lecturers display leaderboard (standings } \\
\text { board) to show the performance of all } \\
\text { students so that students have the spirit } \\
\text { of competition and collaboration in } \\
\text { learning language learning }\end{array}$ \\
\hline Rewards & $\begin{array}{l}\text { Every student is able to answer so the } \\
\text { Lecturer will give rewards (badges, } \\
\text { certificates, achievements) that can be } \\
\text { displayed on student social media or } \\
\text { internal campus websites. }\end{array}$ \\
\hline Onboarding & $\begin{array}{l}\text { The lecturer explained that each material } \\
\text { was adjusted to daily activities with the } \\
\text { aim of providing consistent, fair and } \\
\text { transparent assessment and feedback for } \\
\text { students so that students were able to take } \\
\text { responsibility for themselves }\end{array}$ \\
\hline
\end{tabular}

Learning achievement stores the results of the evaluation of student learning processes to measure latent variables as follows: playback / enjoyment, motivation, and student satisfaction. Correlations between variables and causal relationships between variables will be analyzed using 
statistical methods. With statistics it can be seen how much the results of the teaching and learning process increase each semester.

\section{CONCLUSION}

Gamification techniques for learning show promising results from conventional techniques. Some qualitative measurements use a small sample with two classes of groups in which one learning class with conventional methods and one class using gamification shows learning outcomes with the gamification method in one semester student have an average score of 15 to 25 higher than learning to use conventional methods. Interestingly, learning with gamification techniques in the classroom not only affects students but also affects the lecturers because lecturers will be more innovative in creating gamification techniques. So that proved that gamification is very effective in improving student learning outcomes and not only improves student achievement but also motivation, pleasure, and learning satisfaction are fulfilled. Thus the learning objectives can be maximized with direct and interactive involvement of students and lecturers. Finally, the gamification method can encourage students to get better, higher and satisfying grades for students and lecturers so that learning objectives can be achieved.

\section{References}

[1] Zichermann, G., \& Cunningham, C. . Gamification by Design: Implementing Game Mechanics in Web and Mobile Apps. Sebastopol, CA: O'Reilly Media, 2011

[2] S. Deterding, D. Dixon, R. Khaled, and L. Nacke, "From game design elements to gamefulness," Proc. 15th Int. Acad. MindTrek Conf. Envisioning Futur. Media Environ. - MindTrek '11, no. March 2014, p. $9,2011$.

[3] S. Azmi, N. A. Iahad, and N. Ahmad, "Gamification in online collaborative learning for programming courses: A literature review," ARPN J. Eng. Appl. Sci., vol. 10, no. 23, pp. 18087-18094, 2015.

[4] O. Wongso, Y. Rosmansyah, Yoanes Bandung, "Gamification framework model, based on social engagement in e-learning 2.0",
Conference : IEEE 2nd International Conference

[5] E.M Madalina Jianu and A. Vasilateanu,"Designing of an e-learning system using adaptivity and gamification", IEEE International Systems Engineering Symposium (ISSE), 2017

[6] Roosta, Fatemeh, Fattaneh Taghiyareh and Maedeh Mosharraf. "Personalization of gamification-elements in an e-learning environment based on learners' motivation." $20168^{\text {th }}$ International Symposium onTelecommunications (IST) 637-642., 2016

[7] D. Dicheva, C. Dichev, G. Agre, and G. Angelova,"Gamification in Education: A Systematic Mapping Study Gamification in Education: A Systematic Mapping Study," Educ. Technol. Soc., vol. 18 , no. June, pp. 75-88, 2015.

[8] M. Jackson, "Gamification in Education : A Literature Review List of Figures," 2016.

[9] J. Simões, R. D. Redondo, and A. F. Vilas, "A social gamification framework for a K-6 learning platform," Comput. Human Behav., vol. 29, no. 2, pp. 345-353, 2013.

[10] G. F. Tondello, R. R. Wehbe, L. Diamond, M. Busch, A. Marczewski, and L. E. Nacke, "The Gamification User Types Hexad Scale," Proc. 2016 Annu. Symp. Comput. Interact. Play CHI Play '16, pp. 229-243, 2016

[11] A. F. Aparicio, F. L. G. Vela, J. L. G. Sánchez, and J. L. I. Montes, "Analysis and application of gamification," Proc. 13th Int. Conf. InteracciónPers. - INTERACCION '12, no. May 2015, pp. 1$2,2012$.

[12] Deterding, S., Dixon, D., Khaled, R., \& Nacke, L. "From Game Design Elements to Gamefulness: Defining "Gamification". In A. Lugmayr et al. (Ed.), MindTrek 2011 (pp. 9-15). Tampere, Findland: ACM. 2011

[13] T. Matsumoto, "Motivation Strategy Using Gamification," no. July, pp. $1480-1485,2016$.

14] Anderson, L., \& Krathwohl, D. A., "Taxonomy for Learning, Teaching and Assessing : A Revision of Bloom's Taxonomy of Educational Objectives", New York: Longman, 2001

[15] M. Cervantes and M. A. Montoya, "The Bright and Dark Sides of Microfinance," SSRN Electron. J., 2014

[16]A. Mora, D. Riera, C. González, and J. Arnedo- Moreno, "Gamification: a systematic review of design frameworks," $J$. Comput. High. Educ., vol. 29, no. 3, pp. 516-548, 2017

[17]K. Fleischmann and E. Ariel, "Gamification in Science Education: Gamifying Learning of Microscopic Processes in the Laboratory," Contemp. Educ. Technol., vol. 7, no. 2, pp. 138-159, 2016

[18] S. Deterding, R. Khaled, L. Nacke, and D. Dixon, "Gamification: toward a definition," Chi 2011, pp. 12-15, 2011 